Preprints of the

Max Planck Institute for

Research on Collective Goods

Bonn 2011/16

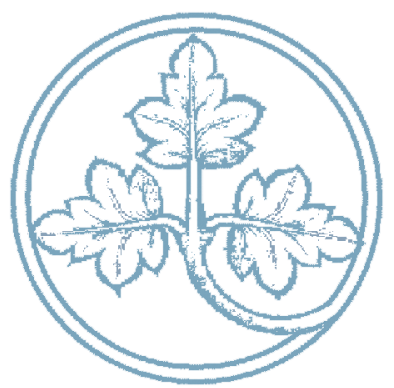

Old Weimar meets New Political Economy:

Democratic Representation in the Party State

Emanuel Towfigh

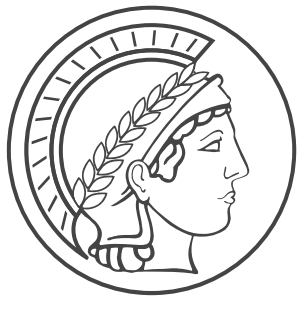




\title{
Old Weimar meets New Political Economy: Democratic Representation in the Party State
}

\author{
Emanuel Towfigh
}

July 2011 


\title{
Old Weimar meets New Political Economy: Democratic Representation in the Party State
}

\author{
Emanuel Towfigh*
}

One of the prominent questions surrounding Weimar Theory of the State was that of the significance and influence of the political parties within the state. From the perspective of constitutional law, parties were as undesirable as they were an "inescapable"1 fact of modern statehood. They appeared to be an absolutely necessary consequence of the emancipation of all classes and social strata: legitimation of state rule was no longer conceivable merely as a natural rule from above; on the other hand, there was no longer a unified bourgeoisie, and it thus seemed impossible for the political whole to be represented by people who felt beholden exclusively to the common weal. The homogeneous "people" had become a heterogeneous "mass". The parties seemed to be a necessity, on the one hand, for active citizens to articulate themselves in the political system and, on the other hand, for state unity not to be torn apart by the power of a plurality of interests leaning in many different directions. Parties could therefore be conceived of as a prerequisite for state organisation: the idea of the "party state" was born. One important protagonist in the discussion on the status of parties within the state structure was the constitutional legal scholar Gerhard Leibholz $\left(1901\right.$ - 1982). ${ }^{2}$ In Weimar times, he was the most prominent representative of party state theory (Parteienstaatslehre), and as someone who "had somehow fallen between the eras", he also actively shaped the party state of the Bonn Republic for over twenty years (1951 - 1971), as a judge at the Federal Constitutional Court (Bundesverfassungsgericht), by significantly influencing legislation on parliamentary, party and electoral law. His persona was therefore a particularly important bridging link between the Weimar Republic and the Federal Republic of Germany, and even

* This text is based on a lecture given on a symposium on Aktualität der Weimarer Staatsrechtslehre at the University of Münster in September 2010; a German version can be found in a volume by the same name, edited by Dr. Ulrich Jan Schröder and Dr. Antje von Ungern-Sternberg (Mohr Siebeck, Tübingen 2011, in press). - I am indebted for valuable comments and discussions on earlier drafts of this paper to Raphael Aigner, Prof. Dr. Christoph Engel, Holger Grefrath, Prof. Dr. Anna-Bettina Kaiser, Prof. Dr. Gregor Kirchhof, Sebastian Lutz-Bachmann, Dr. Niels Petersen, Dr. Ulrich Jan Schröder, Prof. Dr. Indra Spiecker gen. Döhmann, Dr. Antje von Ungern-Sternberg, and Dr. Katharina Towfigh; and I am extremely grateful for assistance with the English translation to Dr. Brian Cooper. The remaining mistakes are, of course, mine.

1 G. Leibholz, Die Wahlrechtsreform und ihre Grundlagen, VVDStRL 7 (1931), 159 (181).

2 Biographical information can be found in an article by A.-B. Kaiser, Gerhard Leibholz, in: R. Voigt/U. Weiß (eds), Handbuch Staatsdenker, Stuttgart 2010, pp. $231 \mathrm{ff}$.

3 This phrase, coined by Rudolf Smend on the occasion of Leibholz' 65th birthday, can be found, amongst other sources, in Unruh, Erinnerungen an Gerhard Leibholz (1901-1982) - Staatsrechtler zwischen den Zeiten, AöR 126 (2001), 61 (90). 
today, his theses are highly topical: "Beyond all eras, Gerhard Leibholz stands for the great tradition of German constitutional theory."4

This topicality manifests itself in his analysis of the difficulties, exacerbated by the parties, of a political representation in the democratic system. For Leibholz, the only valid dimension of the term representation is one that is geared towards representing, or "mirroring" the people in parliament (much in the sense that a randomly drawn sample in empirical research is said to represent the population it was drawn from); for him, the agency aspect (in the sense that someone is legally represented by proxy) is secondary. In the modern mass state, according to him, the parliament (i.e., the people's representation) can no longer be understood as reflecting the people: representation is impossible. However, this also means that the connection between the people's representatives and the people's will has been severed, the normative commitment to the common weal goes nowhere, and this lack of representation creates a legitimation deficit. The parties as Leibholz sees and describes them, and which, for the most part, continue to survive until this day, reinforce this effect dramatically by way of their partiality. His party state doctrine hence aims at allowing the institutions representing the people to become in a certain sense identical with the people by way of newly understood parties, so that it becomes an inescapable condition - normatively as well as factually - that only such decisions can be made that lie in the interest of the people.

This fundamental issue in particular, namely the question of representation mechanisms in a party democracy, is still in effect in the Federal Republic of today, with its system of democratic competition; with conditions becoming ever more complex, e.g., in the case of the today's state in the multi-level system, it has even continued to grow. Even if the solutions proffered by Leibholz have not proved fruitful, it does seem a worthwhile task to take up his specific analysis once again. In doing this, we wish to connect Leibholz' findings, which he made on his path towards a clearer understanding of representation, with newer theoretical approaches, such as those stemming from Public Choice Theory. However, the current study asks more questions than it is capable of offering answers; this can be interpreted as a further indication of just how complex and topical the problem identified by Leibholz is - there is no simple solution.

\section{A. The development of Leibholz' party state theory}

It is beyond the scope of this paper to describe in full detail Leibholz' party state doctrine and the many critical responses to it, and this has already been accomplished in admirable fashion. ${ }^{5}$ It should therefore suffice to provide just a basic outline, inasmuch as this is necessary

Klein, Gerhard Leibholz (1901-1982). Theoretiker der Parteiendemokratie und politischer Denker - ein Leben zwischen den Zeiten, in: F. Loos (ed.), Rechtswissenschaft in Göttingen, Göttingen 1987, pp. $528 \mathrm{ff}$.

5 J. Hecker, Die Parteienstaatslehre von Gerhard Leibholz in der wissenschaftlichen Diskussion, Der Staat 34 (1995), pp. $287 \mathrm{ff}$. 
for our argument. In doing this, I primarily interpret Leibholz' model, and his Weimar papers in particular, as an attempt to give the constitution - rather than the de facto domination by the parties - primacy over the democratic state, and as an attempt to subject the parties to a strict, constitutional regime, curbing their power. Paraphrasing one of Bertolt Brecht's Keuner stories, ${ }^{6}$ we could refer to Leibholz as being severely opposed to parties: he did not (only) wish to abolish them, but rather wanted other parties.

\section{Basics of party state doctrine}

Leibholz developed his party state doctrine in three steps (and over a period of more than 30 years), ${ }^{7}$ which can be paraphrased as follows. Departing from a poignantly phrased analysis (first, descriptive), he first ascertained that - compared to the ideal of representative democracy in the 19th century - there were significant departures in the political reality, as well as severe changes in the status of parliamentarians, in parliamentary debates and in the behavior of parties, all of which led him to conclude that the essence of the political party in the modern state had changed. Against this backdrop, and influenced by other contemporaries such as Carl Schmitt and his teacher Heinrich Triepel (both of whom were affiliates of the "Humanities faction" in the so-called Weimar Methodenstreit), he developed a theory (second, a model resembling a theory) that the classical, liberal representative systems were no longer capable of obtaining the necessary legitimation for a state ${ }^{8}$ according to him, they had become a mere cliché. From these theoretical deliberations, Leibholz (third, normative) deduced that they could be replaced by the "mass-democratic party state" alone, which was antagonistic to representative parliamentarianism: the masses would be activated by the parties, operate within them and hence be bound to the state. In the triangle of populace, parties and state, the parties are given a constitutive part, and without "the interposition of these organisations, the people would today be an amorphous mass, politically powerless and helplessly vegetating to and fro". 9 All politically active citizens would have to organize in such parties, and those who

6 B. Brecht, Geschichten vom Herrn Keuner, "Herr Keuner und die Zeitungen": Herr Keuner met Herr Wirr, who opposed newspapers. "I am a major opponent of newspapers", said Herr Wirr, "I want no newspapers." Herr Keuner said: "I am an even bigger opponent of newspapers: I want other newspapers."

$7 \quad$ G. Leibholz, Repräsentation und der Gestaltwandel der Demokratie im 20. Jahrhundert, 3rd ed., Berlin, 1966. The first edition of his habilitation was published in 1929 and was entitled "Das Wesen der Repräsentation unter besonderer Berücksichtigung des Repräsentativsystems. Ein Beitrag zur allgemeinen Staats- und Verfassungslehre"; the second edition was published — unchanged, one might add — in 1960, with the title used here and maintained in the third edition; it was merely expanded by the lecture "Der Gestaltwandel der Demokratie im 20. Jahrhundert" from 1955. The third edition was published in 1966 and expanded by yet another lecture ("Verfassungsrecht und politische Wirklichkeit"), which Leibholz had held in 1965. It is remarkable that, in the respective prefaces, Leibholz comments on the reception and discussion of his work to date, thus himself testifying, as it were, to its continuity (beyond constitutions). In the context of the party state theory, further central works are Leibholz, Wahlrechtsreform (see footnote [fn.] 1); Leibholz, Volk und Partei im neuen deutschen Verfassungsrecht, DVB1. 1950, pp. 194 ff., and Parteienstaat und Repräsentative Demokratie, DVB1. 1951, pp. 1 ff.

8 Leibholz, Wahlrechtsreform (fn. 1), p. 159 (160 ff. passim).

9 Leibholz, Parteienstaat (fn. 7), p. 3. 
did not commit to a party would "forfeit" their right to participate in the political debate. ${ }^{10}$ In his system, the parties no longer represent the electorate, but become identical with it; ${ }^{11}$ this is why Leibholz sees his party state as a variant of plebiscitary democracy. However, the parties in Leibholz' world have no more in common with our modern parties than the name. A constant plebiscite, as it were, they become totally absorbed in the state. In Leibholz' view, the parliament merely registers what has been decided by the parties; the Member of Parliament is hence "an exponent of his party". "From these normative reflections, Leibholz drew his own concrete legal-policy conclusions: amongst these are the imperative mandate - for parliamentarians have to be bound to the quasi-plebiscitary will of the people, as it is expressed in the parties; further, the democratic inner constitution of the parties - for only through this can we be sure that the true will of the people is brought to bear in the parties, allowing for an identity of the rulers and the ruled alike; and finally, the status of the parties as a constitutional organ, for political parties are much more important now than elections, with regard to forming a political will that hence legitimizes the state (Leibholz ultimately considers elections dispensable). Under the German Constitution (Grundgesetz, GG), he altered these assumptions in view of Article $38 \mathrm{GG}$, which in his opinion ran counter to the system, but he also perceived a tension between Articles $21 \mathrm{GG}$ and $38 \mathrm{GG}$ and was reluctant to adjust this tension, which he claimed went back merely to an anachronistic perception of representation in the constitution: "the fundamentals of representative parliamentarianism, as they are expressed in Art. 38 and in the following clauses, can today only be seen as rearguard action, as they fulfill the function of warding off the most extreme consequences of the modern party state. [...] A view that would give representative parliamentarianism more impact and would attempt to use it in order to alleviate the dangers of the party state would overlook the fact that the modern party state can no longer be corrected by means of representative parliamentarianism."13

This phrase also shows that Leibholz, even in later years, did not in the least have the uninterruptedly positive relationship with parties that he was said to have. Rather, his Parteienstaatslehre can be understood, from today's perspective, as an attempt to master the problem of democratic legitimation of the mass state. At the core of his thinking lies the concept of representation of the people in the democratic state, a concept Leibholz perceived as being central to legitimation. ${ }^{14}$ Although his method can be contested with regard to certain individual aspects, he had recognized that neither parliamentarians nor parties (to which the MPs were not legally bound, although they were bound in other ways) were capable of representing the people: the parliamentarians were incapable because of their link to the parties, and

10 Leibholz, Wahlrechtsreform (fn. 1), p. 188.

11 See, in particular, Leibholz, Parteienstaat (fn. 7), p. 4: "The mediatization of the people by the parties is inevitable in the modern democratic party state. Indeed, it is even essential to its character. The parties 'are', to all intents and purposes, 'the' people." referee.

13 Leibholz, Parteienstaat (fn.7), p. 7.

14 Leibholz Repräsentation (fn.7), pp. 98 ff. 
the parties were incapable because they were floating freely and without any linkage in the political space. ${ }^{15}$ Representation was to him an insincere and unstable construction. For Leibholz, the decisive part of the legitimating chain was missing, with which the people would be able to bind the parliament - and hence the state - to itself. He therefore perceived the one element that fundamentally legitimized democracy as vanishing. ${ }^{16}$ His theory was not anti-democratic, as some would have it; ${ }^{17}$ rather, it is an attempt to secure the people's influence on the state. If Members of Parliament, for logistical or organizational reasons, were no longer irreversibly bound to the people, but instead to their parties, then the parties had to be bound to the people. From this, Leibholz postulated that only a citizen who was affiliated with a party was capable of acting politically, i.e., a politically active citizen or Aktivbürger. The populace (in the sense of Aktivbürger) and the government (i.e., the leadership as determined by the political parties) become "identical", in Leibholz' view, and from the demand for a democratic inner organization of the parties one might deduce that it is imperative for their parliamentarians be bound to party decisions; parliament would hence merely have a function of registering the will of the people, as it has become distilled in the parties. Not the parliamentarian is legitimized, but rather the party. In view of the fact that the people were hardly being represented, all these instruments were conceived as an institutional safeguarding the efficiency of the people's will in the state, and in fact they were established to serve the protection of democracy; they were intended as the opposite of anti-democratic.

\section{Criticism of the Party state doctrine}

Leibholz' Party State Doctrine, or Parteienstaatslehre - which during the Weimar Republic was little more than a thesis, later becoming a doctrine in the Federal Republic and finally turning into his trademark ${ }^{18}$ — received much criticism in the fields of political science and constitutional theory, both in the Weimar Republic and in the Federal Republic of Germany. ${ }^{19}$

On the one hand, there was a methodological criticism of his phenomenological reconstruction of constitutional reality. In the Weimar years, Arnold Köttgen, ${ }^{20}$ Hans Julius Wolff ${ }^{21}$ and Hans Nawiasky ${ }^{22}$ were at the fore of those who criticized the combination of both humanitiesrelated and legal definitions of the term representation. The apparent Wesensgesetze, or essential characteristics, of representation were, in their view, not only "anything but evident",3

15 Leibholz, Repräsentation (fn.7), pp. $103 \mathrm{f}$.

16 Hecker, Parteienstaatslehre (fn. 5), pp. $289 \mathrm{ff}$.

17 Kaiser, Leibholz (fn. 2), p. 231; Hecker, Parteienstaatslehre (fn. 5), p. 299.

18 Hecker, Parteienstaatslehre (fn. 5), p. 287 (291).

19 On the development of Leibholz' theses and their reception, cf. the detailed account in Hecker, Parteienstaatslehre (fn. 5), pp. 287 ff.

20 AöR 19 (1930), pp. $290 \mathrm{ff}$.

21 Archiv für Rechts- und Wirtschaftsphilosophie 24 (1930), pp. 392 ff.

22 Leipziger Zeitschrift für deutsches Recht 26 (1932), pp. $130 \mathrm{f}$.

23 H. J. Wolff, Archiv für Rechts- und Wirtschaftsphilosophie 24 (1930), p. 392 (397). 
and in need of proof, but they were of an intuitive nature, i.e., ultimately beyond any intersubjective and empirical examination. Further, "positive law is not bound by any possible Wesensgesetze". ${ }^{24}$ Hasso Hofmann took up this critique much later by coining the accurate and conciliatory phrase that Parteienstaatslehre drew "conclusions at the theoretical level of political sociology, and not necessarily at the level of concrete constitutional law" ${ }^{25}$ In addition, Hofmann sees the depiction of constitutional reality as based on an ahistorically idealizing perspective of history, which in itself is also vulnerable: for $19^{\text {th }}$-century parliamentarianism had also seen pluralism of interests (the societal groups and classes were not as homogeneous as Leibholz made them out to be), and early forms of the mandatory party vote in parliament, for instance, were present. Conversely, modern "mass-state" democracy also comprises a pronounced personal element. In the political-science arena of the Federal Republic, the categorization of modern democracy as a structural type of identity was deemed particularly untenable. ${ }^{26}$ Further, Leibholz' characterization of parties sparked criticism: on the one hand, his theory degraded it, instrumentalizing it as "mouthpieces" of popular will, and on the other hand, he revered them as bearers of political will formation. Either way, in the later Federal Republic, and in the view of more recent constitutional theory, both viewpoints became incompatible with the involvement of the parties in political will formation; this involvement constitutes a cornerstone of Article 21 of the Grundgesetz and is based on individual decisions of party members.

Finally, Leibholz' model of party-state democracy was also subject to much criticism. On the one hand, he was accused of being close to a dictatorial one-party regime (although such a scenario was precisely what Leibholz strove to avoid), ${ }^{27}$ and on the other hand, people claimed it displayed disdain for the concept of parties itself, which, these critics maintained, would be doomed to failure and would appear to show a severe lack of any veracity.

\section{B. The Problem of Representation in the Party state}

As mentioned before, the question of democratic representation lay at the core of Leibholz' reflections, and this is shown by the fact that he kept adjusting and developing his Parteienstaatslehre to the new situation under the Grundgesetz during the time of the Bonn Republic. This was all the more remarkable given that there was competition from another democratic party-state model that attempted to harmonize Art. 21 and Art. 38 GG. Neither was able to alleviate Leibholz' more basic problem.

24 A. Köttgen, AöR 19 (1930), p. 290 (291).

25 H. Hofmann, Parlamentarische Repräsentation in der parteienstaatlichen Demokratie, in Hofmann, Recht — Politik - Verfassung, Frankfurt 1986, p. 249 (255).

26 Cf. also K. Hesse, Die verfassungsrechtliche Stellung der politischen Parteien im modernen Staat, VVDStRL 17, 10 (21). Hesse refers directly to Leibholz' writings on the Federal state, e.g., in fn. 28 and 37.

Leibholz, Parteienstaat (fn. 7), p. 4. 


\section{The Party state theory in the federal republic}

In order to show just how topical Leibholz' reflections surrounding the term representation are, we need to elaborate briefly on the criticism of his ideas, and how this criticism developed and accentuated the alternative model as it is applied in the Federal Republic to this day. As Konrad Hesse outlined powerfully in his influential essay on theory of the state in $1958,{ }^{28}$ Art. $21 \mathrm{GG}$ and Art. $38 \mathrm{GG}$ are not opposites, but instead to be understood as a synthesis. Hence, parties perform a central role in forming political will, without being the bearers of political will formation. They still remain voluntarily founded associations that perform important tasks in recruiting the political leadership, which then requires legitimation by a majority. If they are in government, they are the "link in the legitimation chain between the people and the political leadership", ${ }^{29}$ and if they are in opposition, they perform a control function, assuring that power is not abused. Finally, as mediators of a free and open process of political will formation, they bring together political goals in programs, molding them in discourse and applying them to the commonwealth. At the center of the political process, however, is the free parliamentarian who is committed to the public weal, and the stage of his political actions is the parliament: "If rational personalities use their freedom properly, i.e., rationally, then it may be said of such a [parliamentary] discussion that it has a creative and constructive character. It need not fear public scrutiny. On the contrary, with its help, the people should participate in the political deliberations of its representatives." ${ }^{30}$ This is the way we understand the characteristic essence of parties today, and the image of parties as mouthpieces do not fit this picture, today's understanding seem irreconcilable with Leibholz' party state theory.

\section{The political reality}

Even a superficial glance at the political reality shows that the picture we have just outlined has become an unreal cliché. One may say without exaggeration that, if one wishes to analyze closely the political reality today, it is simply not compatible with the constitutional norm of Art. 38 GG. Nowadays, the parties dominate elections. With the help of the parliamentary groups, the legislation at federal and at land level remains in their hands. Without them, no treaty is signed and no budget passed. They are called to control the executive branch, and just as they also form the government (recall, for instance, the recent coalition negotiations), they play a major role in the election of the Federal President. The parliamentary groups' size

28 Hesse, Parteien (fn. 26), pp. 10 ff. In several elaborations, one can sense how Hesse, usually without being explicit, develops his model as a form of dissociation from Leibholz. Very often, Hesse employs arguments that render Leibholz' reflections even in the way they are phrased. Nonetheless, as his footnotes show (cf., however, the proof in fn. 26 above), he barely deals explicitly with Leibholz or with the ample Weimar discussion; rather, he celebrates the caesura of the Grundgesetz - even though the title of his work, with its recourse to the "modern state", might have suggested otherwise.

29 Hesse, Parteien (fn. 26), p. 21.

30 Leibholz, Repräsentation (fn. 7), p. 254. 
decides how many representatives the Bundestag sends to the supranational parliamentary assemblies. At local-authority level, too, the parties' influence continues to grow, for instance if one considers how both state and local parliaments are called to send representatives to committees that play a huge part in public life.

The above paragraph is a forceful example for just how topical Leibholz' reflections still are - for these lines stem, word for word, from his very own pen, namely from a lecture he held in 1965 on the occasion of the $40^{\text {th }}$ anniversary of the Max Planck Institute for Comparative Public Law and International Law. ${ }^{31}$ Had I not revealed this here, my assumption is that it would hardly have been noticed that these words were spoken 45 years ago; indeed, one might have asked why this example was not elaborated upon in more colorful detail - the election of President Wulff, for instance, which was in no small measure the result of party motives, and the so-called Fraktionsdisziplin (in other words, the tacit expectation that the parliamentary groups vote as one), which is expected even in the Federal Convention, are not the only obvious examples from the more recent past.

The dominance of the political parties in the political process is undisputed today. It seems unnecessary to list the countless voices from science and everyday politics. Bearing in mind the continuities of German Constitutional Theory, I would like to limit myself to only one quote from Stolleis' lecture on the Staatsrechtslehrertagung 1985: " "The fact itself is undeniable. The selection of administrative personnel according to their party affiliation and reflecting the relative proportions of parties, and the spoils system are firmly a part of the party state in administration and self-administration, as well as in the transitions towards a societal power that is being increasingly organized under private law. The parties hold the career ladders, discipline dissenters and reward any successful defense of terrain. This is a matter of course in the case of local self-administration, which has for a long time now been firmly established by the party state as the bottom level of parliamentarianism." The system of democratic competition, as developed by Hesse, did not work against this development, but instead aided it - however, it never intended to confront this challenge. Rather, the constitutional sanctioning of that model meant that the attempt to tame the parties was given up.

In his preface to the third edition of his habilitation thesis, Wesen der Repräsentation, Leibholz declares "the question of how political will is formed, particularly in a democracy", to be a "crucial problem of political science"; this, in his view, "has been shown by centuries of Constitutional Theory history". If we take this issue as a benchmark, then what ultimately distinguishes Leibholz from Hesse is their viewpoint on how the sovereign will becomes a reality in the democratic state - and hence their relationship with the idea of representation. In Hesse's Constitutional Theory lecture, the word representation does not even feature. On the contrary: citing Joseph Schumpeter, he explicitly expounds on democracy meaning "not

31 Leibholz, Repräsentation, (fn. 7), p. 254.

32 M. Stolleis, Parteienstaatlichkeit - Krisensymptome des demokratischen Verfassungsstaats?, VVDStRL 44, pp. $7 \mathrm{ff}$. 
dominance of the people, but dominance 'for the people",; ${ }^{33}$ he therefore contrasts what Lincoln referred to in his Gettysburg Address as two harmonizing notes in a triad. As late as 1985, Stolleis deemed it necessary, in his Staatsrechtslehrertagung lecture, to clarify that 'Leibholz' distinction of people and people of the party and his dichotomy of representative system and party state, which from the beginning was fraught with exaggeration, was out of touch with reality, used antiquated philosophical premises and has today become utterly problematic. The representative system and the party state are indeed very compatible. [...] Party demands, moral constraints and constraints of interest are just as normal for the socially integrated individual called parliamentarian as the intended legal effects of these constraints are null and void." $" 34$

In this particular regard, Leibholz' and Hesse's perception of, or opinion on, the reality and the concomitant views on democratic theory differ from Stolleis' views. Both men recognized that, in the political arena, a (democratic) state was no longer attainable with the classic concept of representation in the sense of an original reflection of popular will; and while Leibholz harbored the ambition to replace it with something (namely, his idea of identity), Hesse tacitly gave it up, in order to arrive at his moderate synthesis of the constitutional principles of Art. 21 and Art. 38 GG. Stolleis, on the other hand, reverted back to cultivating the representation myth, envisaging the institutional safeguarding of representation. ${ }^{35}$ For him, representation is an indispensable fiction that facilitates attributing the decisions of the sovereign's elected political leadership to the sovereign - i.e., the people. For this attribution to be legitimate and accepted by the sovereign, the political decision has to be made within a clear mandate; here, proportional representation — in the sense of the election of a program serves as the specification of a "framework mandate". One may speculate that Stolleis has the same reasons for suggesting this interpretation as Leibholz had for proffering the principle of identity as an alternative: to safeguard democracy, in order to prevent a legitimation deficit, and due to a lack of an alternative that, Stolleis' story told us, not even Leibholz could have delivered.

In comparison with the principle of representation, however, the party-state democracy is bound to seem just as untrustworthy as it was for the evaluation based on Leibholz' identity principle. For it does seem implausible that a free mandate, as Stolleis suggested, should be content with socially binding party demands and interest constraints existing without being legally sanctionable. At any rate, Stolleis appears to be one of the few people who criticised Leibholz with regard to his elaborations on the theoretical problem of representation; the rest is helpless silence. That, however, is no less surprising, given that the term representation remains one of the most enigmatic terms in the realm of political theory. ${ }^{36}$ It belongs to the

33 Hesse, Parteien (fn. 26), pp. 19 f.; the emphasis is in the original.

34 Stolleis, Parteienstaatlichkeit (fn. 32), pp. $33 \mathrm{ff}$.

35 Stolleis, Parteienstaatlichkeit (fn. 32), p. 36.

36 Instead of citing later scholars, I refer the reader to V. Mittendorf, Die Qualität kollektiver Entscheidungen, Frankfurt 2009, pp. 25 ff. Further sources are given here. 
oldest problems of statehood - and not merely democratic statehood - and has created entirely new theoretical problems since the abolishment of the monarchy. The Weimar debate was unable to solve the question, and to this day it remains one of the unsolved mysteries of Constitutional Theory. ${ }^{37}$

\section{The problem of representation in light of new political economy}

The differences between Leibholz, Hesse and Stolleis may be understood as dissent on the perception of reality. New Political Economy, and in our case even more precisely approaches of Public Choice Theory, provide hence an ideal frame of reference, because they provide an analytic toolkit for understanding and evaluating this reality. This should contribute to a clearer understanding of the possibilities and limits of the concept of representation.

Public Choice Theory ${ }^{38}$ focuses on conflicts of individual and collective rationality in political actors - be they voters, politicians, civil servants, administrations, pressure groups and so on. Their cognitive interest is primarily descriptive and analytical. Public Choice Theory shall serve here to contrast the normative standard of the constitution — in particular of Art. $38 \mathrm{GG}$ - with the reality observed. It sees itself predominantly as a further perspective to reflect upon politics, the state and administration. It breaks with a more "romantic" understanding of politics, ${ }^{39}$ which dominated political economics until well into the 1950 s. Until that time, economists and political scientists gave actors on the political stage a different treatment than they gave market actors. In the markets, actors were characterized as being interested in maximizing their own self-interest without being in full knowledge of the market and its conditions. In politics, on the other hand, the same individuals were regarded as being omniscient and exclusively at the service of the public weal. This is the perspective that Theory of the State adopted during the Weimar years (albeit without ever reflecting or naming this), and even today it can be considered an unspoken premise of many concepts of Constitutional Theory. Public Choice Theory rejected this view. On the one hand, it expanded the methodological individualism, i.e., the explanation of how systems (for instance, organizations) function and act, to the political process also; on the other hand, it applied the homo oeconomicus model, as a descriptive perspective, to the actors in the political sphere.

From Economics and Decision Theory, a theoretical framework was developed that could be applied to politics. At its core lie the questions about how decisions by individual rational actors concerning the community affect the collective welfare, how negative effects can be

37 Cf., e.g., C. Möllers, Expressive versus repräsentative Demokratie, in: R. Kreide/A. Niederberger (eds), Transnationale Verrechtlichung. Nationale Demokratien im Kontext globaler Politik, Frankfurt/New York 2008, pp. $160 \mathrm{ff}$.

38 As an introduction to the themes dealt with here, see E. V. Towfigh/N. Petersen, Ökonomische Methoden im Recht. Eine Einführung für Juristen, Tübingen 2010, § 6, pp. 133 ff.

39 Proponents of the emerging Public Choice Theory referred to the classic image political science had of the political actors das "romantic"; such actors could be "voters", "politicians" and "bureaucrats"; cf., e.g., G. Tullock, The Politics of Bureaucracy, Washington 1965. 
explained, and the most positive effects possible ensured (Public Choice Theory), and how the countless individual interests can best be aggregated to a single collective decision (Social Choice Theory). All this is considered bearing in mind that market mechanisms, which lead to a disclosure of the market actors' true preferences, are lacking just as much as the possibility to harmonize, through individual incentives, the selfish pursuits of the acting individuals with higher interests: in privately organized enterprises, this can be achieved by means of appropriate contract policies, but in the kind of political system engrained in Public Choice Theory, no actor has an incentive to counteract an individual selfish pursuit if it is endangering the public interest.

In its basic form, Public Choice Theory meets three presumptions: ${ }^{40}$

- First, resource allocation is determined by the political process, rather than by an elected individual who is "benevolent" or "omniscient".

- Second, it is assumed that the political process is best understood as a strategic interaction between the participating groups - primarily voters, politicians and administrations.

- Third, every actor strives to maximize his or her individual benefit. For a typical voter, this means the general personal benefit, as known from the homo oeconomicus; for the archetypal politician, the individual benefit, according to theory, is primarily maximized if the number of votes is maximized; and finally, the archetypal bureaucrat attempts to increase his administration's budget as much as possible.

From these presumptions, Public Choice Theory draws conclusions for rational behavior on the part of the political actors, using these conclusions to attempt an explanation for the political life and the behavior that can be observed in the political process. Up until now, however, the role of the parties remains relatively unclear.

In the following, I wish to use Public Choice Theory to identify three problematic areas that are in opposition to the idea of representation. Following the Weimar discussion, I initially wish to show that parties can limit parliamentarians' representational effect in the triangle formed by citizens, parliamentarians and party. Leibholz was amongst those who recognized this. In a second step, I shall expand this idea, showing that even without parties, i.e., in the relation between citizens and parliamentarians, a whole series of results can take effect - results that are incompatible with the classic concept of representation as a visualization of the entire people. In a third step, finally, I focus on the reference point of representation - popular will - and demonstrate that, ultimately, there cannot be any such thing.

40 For the (limited) aims of this contribution, it should suffice to discuss only the central and most basic presumptions; many of these presumptions and models have been developed and further refined since the inception of Public Choice Theory some six decades ago, or else they have been modified to suit special applications. All this, however, cannot be dealt with in depth here. 


\section{Representation in the party state}

Leibholz' intuition that representation in the classic sense is hardly possible in the party state appears to be confirmed with the help of this theory. In principle, Public Choice Theory assumes that politicians are eager to maximize the number of votes to attain an office or mandate. In the party state, it is hardly possible for a parliamentarian to achieve this alone - telling proof of this can be seen in the fact that there is not a single representative in the German Bundestag (and in many other "professional" European parliaments) who is not a member of a party. Any politician is therefore bound to a party and to its rationality if he or she continues to pursue the underlying goal of maximizing votes; if politicians do not subject themselves to party reason, the party will give preference to another candidate in that competitive game candidates play to gain favor with the parties they need for support - when they, in turn, seek support from voters. If, in a system without parties, politicians incentivetheoretically stick to whatever program might appear to win their favor with the voters, in a party state they must also take into account the favor of the party.

\section{Pursuing particular interests}

It is precisely this aspect that Leibholz views as problematic. Constitutionally - i.e., normatively - voters can follow their own interests; parliamentarians, however, are beholden to the public weal. ${ }^{41}$ On the other hand, the parties, although privileged by Art. 21 GG because of their commitment to the public weal, are free political associations and hence not beholden to common welfare. There are indeed substantial incentives to develop policies that are in the interest of the majority (although one may question whether this majority can be equated with the popular will); however, parties are free to pursue particular interests also. So, if parliamentarians submit to the parties (if, quite literally, they toe the party line), then there is a danger that they might effectively (and increasingly) embrace the particular interests promoted by their parties, despite being exclusively bound to the public weal normatively. From an empirical perspective, this means that, besides the incentives an individual parliamentarian already has (in accordance with Public Choice Theory, and as long as his or her own benefits are not maximized while the collective interest is being pursued) to deviate from the normative commitment to common welfare, further incentives are created by the influence of the parties, namely incentives to pursue one's own particular interests. If a candidate indeed strives to advance only common-welfare matters, and if he can only gain a mandate with the help of a political party, while pursuing these particular interests, then he can either give up hope entirely or else seek success in pursuing both collective and particular interests. As we shall see later, this is the case for parties that exclusively serve a particular clientele, rather than for the main political parties (Volksparteien, or people's parties, in German). In this regard, parties may have the effect of detaining parliamentarians from their (normative) function as representatives of the entire people. In line with Public Choice Theory, the parties 
bring their own new incentives into the system, thereby changing the behavior of politicians, be they candidates or members of parliament.

\section{Party behavior as a result of the behavior of inner-party actors}

If we take Public Choice Theory seriously, the parties themselves are no monolithic blocks; they, too, should be subjected to methodological individualism. In other words, we should assume that there is no uniform, overarching party will as such, but that what we assume to be party behavior is ultimately the result of the behavior of actors who operate within the party, following their own individual interests. Various actors are organized within a party: First, there is the party base. The party base stands for a particular political orientation, it wishes to participate in decisions relating to themes and personnel policy, and it strives to implement a political program by convincing fellow citizens to support it - primarily by casting their vote for that party in elections, so that the party and its personnel can attain power. Within the party base, there are personalities who wish to exert influence directly by taking political responsibility for actions; frequently these personalities want to make politics their profession. In order to get closer to this goal, they ultimately have to undergo the normal proceedings of this democratic microcosm. Hence, before they can campaign directly with the voters, they must ensure that the party base votes for them; we have sketched above what kind of behavioral incentives that might entail. Finally, there are the party officials, who are ultimately the ones who enter the political ring — which is obviously the reason, as Leibholz remarks, why those actors with the highest political authority (for instance a head of government) usually also aim for the party presidency. Only in this way can they ensure a party's disciplinary function for all members of parliament, so as to be able to implement their program. ${ }^{42}$

\section{Focusing on the median voter}

It seems important to point out that such a system points to the median - to the political center ground. It is a truism in politics nowadays that the main political parties can only win elections in the political center ground. For political elections, this means that these main parties at least have to campaign for the median voter, i.e. the voter with that set of preferences (expressed in his electoral decision) round whom cluster as many voters to the left as to the right. For theory, it is irrelevant what the actual voter distribution looks like. If we observe a normal distribution, candidates meet at the center of the political spectrum. If our spectrum

42 Finally, it should be added that the party list system intensifies the political effects generated by the parties. For this institutional organization means that the party becomes more important for the candidate than the voters, because the party can secure a seat even if the candidate is unsuccessful with the voters; the party provides him not only with the logistical and financial means to campaign for votes, but it can also assure him of a promising position on the party list much the way an insurance works. Yet, only such parties can offer a promising place on a party list in electoral system with proportional representation whose elected representatives convince the electorate. In this text, I can of course only rudimentary touch upon these aspects that have been subject to intensive research in political science and political economy. 
shows a higher number of votes on one particular side, then the median voter moves to the right or the left, so that candidates also compete for the median voter to the right or the left of the arithmetic center (which can amount to a rather extreme political position within that spectrum). ${ }^{43}$

The theoretical explanation of this phenomenon stems from the median voter theorem developed by Anthony Downs. ${ }^{44}$ Downs had been inspired by an article written by the economist Harold Hotelling ${ }^{45}$. He orients his theory along Schumpeter's democracy-theoretic concepts, according to which candidates (and, more relevant to our question, also political parties) are in competition for votes and adjust their programs accordingly, so as to gain as many votes as possible. ${ }^{46}$ This is the central assumption in Downs' theory. If we apply these assumptions as a basis, then we must conclude that the parties (as well as party-independent candidates) always cluster around the median voter. If one party or candidate within a party moves slightly to the left or right in the political spectrum, then the other party or another candidate can immediately move up and gather those voters, closer to the center, who were left behind by the other candidate.

The median voter effect is amplified by political parties. Extensions to the Downsian modelindicate that left parties rather field candidates leaning towards their own right wing while candidates oriented to the left prevail in right-wing parties. This is because with these candidates a party's prospects to win median voter votes rises: While voters at the margins will vote for the proximal candidate anyways, the battle for the center votes is decisive. The elite selection process within parties therefore supports "medianization". Democratic constitutionality within the parties, which Leibholz championed so vehemently, albeit primarily for other reasons, ${ }^{47}$ leads to the party leadership also having to win over the median voter within the party, so that the frightful experience of the Führerprinzip as dogma is eased. ${ }^{48}$

Now, what does this medianization of politics mean for the classic representation model, according to which parliamentarians congregate in parliament as representatives of the entire people, in order to reproduce the will of the sovereign there and to make it a state reality? On the one hand, one might say that the orientation towards the median of political opinion might lead to representation of the "true popular will" (which we still have to discuss). Should we not be glad about this, given that above we have flagellated the concentration on particular

43 It seems important to note that the median voter theorem, giving expression to a strong political intuition, can only be proven mathematically with a number of restricting assumptions, among which are a onedimensional policy space, a majoritarian two-party first-past-the-post system, and single-peaked voter preferences that in this pure form might only be rarely met in reality.

44 A. Downs, An Economic Theory of Democracy, New York 1957.

45 H. Hotelling, Stability in Competition, Economic Journal 39 (1929), 41.

46 E.g., J. Schumpeter, Capitalism, Socialism, and Democracy (1942), New York 1975, pp. 269 ff. (Chapter XXII).

47 Leibholz, Repräsentation (fn. 7), pp. $246 \mathrm{ff}$.

48 Cf. A. Hirschman, Exit, Voice, Loyalty. Responses to decline in firms, organisations, and states. Cambridge (Mass.) 1970. 
interests? The answer is not an easy one as we lack benchmarks within our model framework. But the observation that the concentration on the median voter ultimately also prevents representation of the entire people, once it becomes a "dictatorship" of the median voter, suggest the conclusion that paradoxically not only the pursuit of special interests but also the medianization may lead to a decrease in the perceived representativity of a political system. This would explain parts of the recent political discourse to the right and the left of the political spectrum, according to which a substantial number of citizens (and voters) no longer feels represented.

\section{Consequences}

We can safely say that, from the theoretical approach of Public Choice Theory, it is possible to find arguments in support of Leibholz' basic hypothesis, for they show that the parliamentarian in the party state is not only a representative of the (entire) people and helps the will of the people to be heard in parliament, but that the parliamentarian is primarily an exponent of his party, and that for this reason the idealizing concept of representation of the entire people by parliamentarians in the party state is a utopia.

Interestingly, parties can pose a problem for representation in two different ways: on the one hand, they can divert attention from representation of the entire people by embracing particular interests and imposing them on their representative. On the other hand, however, the orientation towards the median voter might be precisely what could lead to the entire political spectrum, in other words the entire people, no longer being represented. Hence, parties distort representation, and once again we can see that true representation of popular will is not possible: either the interests of the center of the electorate are neglected - or else the will of voters on the fringe of the spectrum is not taken into account. To look for the solution in a personalized form of proportional representation would certainly not suffice, as long as the candidates are, de facto, bound by their party membership. ${ }^{49}$

\section{The parliamentarian as a representative of the entire people}

Having analyzed the difficulties representation faces in the party state, we now turn to the question whether representation can function without parties, in other words in a relationship between citizen and representative. Public Choice Theory can help explain why we often see how parliamentarians, in their role as representatives of the entire people, follow their particular interests rather than pursuing a common-welfare goal, which can be defined in many ways; this pursuit of individual goals is frequently justified by seemingly rational arguments. And the parties would not even be necessary for this: the political system creates substantial incentives that make the pursuit of such individual interests attractive.

On this, see above, III. 1. b). 


\section{The influence of particular interests}

A popular example from Public Choice Theory is the view of what societal discourse refers to as lobbyism: mechanisms of promoting particular interests. The basic problem is easily explained: ${ }^{50}$ small groups with particularly pronounced interests profit from the "rational ignorance" of the majority of the electorate, as well as from the interest of politicians in maximizing votes. At the core of this effect of particular interests lies a specific political decision that promises a huge benefit to a small group of voters, but also goes hand in hand with an external effect, namely minor costs for a much larger group of other voters. The small group of voters has a particular interest in organizing and acting concertedly. From the perspective of politicians, the theme dominates the group's voting decision; if politicians wish to assemble this group of voters behind them, then they have to comply with their demands. On the other hand, the larger group of voters, which bears the cost of this decision, is usually not interested in the concrete plan, for rational reasons, because the effect on personal wealth lies beneath the level of perception, i.e., because the costs of informing oneself about these policy decisions and their effects are higher than the benefit of having this information - even if the information alone could avert the decision. This is the reason why politicians have strong incentives to avail of such special interests, even if that is not in the interest of the common welfare (however that may be defined). For they are rewarded by the small group and usually not sanctioned by the large one. According to Public Choice Theory, pursuing special interests is particularly attractive to politicians if the costs are borne by people who do not have a vote as a result of a political constellation: for instance, if future generations are burdened this is referred to as "political short-sightedness" - or people from neighboring countries or regions in which the respective politician or party is not up for election at that time. ${ }^{51}$ The problem becomes particularly dramatic if it multiplies because of political logrolling, ${ }^{52}$ and external effects can arise in groups that are not involved in the election in question. For instance, if a party only lines up in cities A, B and C, external effects could remain unconsidered in $\mathrm{D}$ and $\mathrm{E}$.

One example for this might be the discussion that followed the German Federal election in 2009 , after which value-added tax was reduced from $19 \%$ to $7 \%$ for overnight stays in hotels. The hoteliers had no possibility of raising their prices during the financial crisis. By reducing the VAT rate, a reduction that was rarely passed on to the customer, the hotel industry was able to profit from a 12 percentage points increase in one single step; these had to be compensated elsewhere, either as a shortfall in taxes (no form of reciprocal financing was decided) or else by means of an increased debt to be borne by future generations. The theme

50 Cf. M. Olson, The Logic of Collective Action. Public Goods and the Theory of Groups, Cambridge (Mass.), 1965.

51 Cf. N. Petersen, Demokratie und Grundgesetz - Veränderungen des Demokratieprinzips in Art. 20 Abs. 2 GG angesichts der Herausforderungen moderner Staatlichkeit, JöR 58 (2010), pp. 137 ff.

52 In the literature on Public Choice, this phenomenon is called log rolling. An impressive current example from the U.S. Senate may be consulted on http://www.c-spanvideo.org/program/284890-1 at 150:59 (= 2:30:59). 
was hotly debated in the media, because the government party that had pushed this reduction through had been given substantial donations by hoteliers; otherwise, the reduction would never have been noticed, on account of the rational ignorance of the electorate.

Public Choice Theory explains here what already makes sense to us from our own life experience. However, at the same time it provides us with a theoretical framework, with the help of which we can make predictions not just from anecdotal experience, but from models.

\section{The efficiency of representation}

Another important aspect of our issue is the uneven distribution of information (information asymmetry) between voters and politicians. However, it is possible for economics to have solution concepts ready. Such problems are generally dealt with by the principal-agent theory, which is rationally and theoretically founded and pertains to the field of microeconomics: in the models, the "agent" performs a task at the behest of the "principal", from which the principal profits; the agent receives a contractually defined "reward" from the principal. Besides the classic working relation, such "contracts" may describe any kind of service, and they may also be applied to the relation between voters and politicians. ${ }^{53}$ For the problems of adverse selection, ${ }^{54}$ as described here, it has developed solution models that may be translated to the political reality.

If we look at the parliamentarian's mandate as an application for information asymmetries in a principal-agent relation, then the problem for the voter lies especially in the fact that a parliamentarian's performance is hard to assess in advance. ${ }^{55}$ One possibility would be for the candidate to display his qualification by means of a credible signal: this would facilitate the well-informed contract party (i.e., the parliamentarian) to overcome the information asymmetry in the elections. ${ }^{56}$ What is more interesting from the point-of-view of contract theory, however, is the opposite constellation, in which it is not the agent who signals a qualification, but the principal who compels the agent (the parliamentarian) - through cunning contract design — to disclose hidden information before the elections (this is referred to as screening).

53 In political economics, the relation between citizens and state organs is regarded as being analogous to a principal-agent relation. Here, the citizens are seen as principals and the state organs are seen as agents. See more details on this in J. Buchanan, The Limits of Liberty, 1975.

54 Cf. A. Nicklisch/N. Petersen, Vertragstheorie, in: Towfigh/Petersen (fn. 38), pp. 121 f. Adverse selection describes a mechanism in which there is a downward spiral as a result of information asymmetry between the principal (e.g., a buyer who is ultimately not capable of reliably determining the quality of a product) and the agent (e.g., a seller who knows the product and its quality well): worse and worse goods are sold at ever lower prices, because the averaged price ( = the weighted average of the relation between good and poor products on the market) offered by the buyer, who is burdened with an information risk, is only attractive for those buyers whose product is poor, i.e., worth less than the average price. Those who have good products stay away from the market, which is why we speak of a market mechanism leads to an adverse selection.

55 Cf. G. Akerlof, The Market for "Lemmons". Quality Uncertainty and the Market Mechanism, QJE 84 (1970), pp. $488 \mathrm{ff}$.

56 Accession to a party might well be such a signal, cf. J. Snyder \& M. Ting, An Informational Rationale for Political Parties, AJPS 46 (2002), pp. 90 ff. 
Problems can also occur after elections, however, for instance if parliamentarians cannot be properly observed in the performance of their actions. Certain political goals not being achieved may be due to a coalition partner, the poor economy or even a substantial donation to the party or the influence of lobbyists. Such "post-contractual" uncertainty is termed moral hazard by economists: the agent may be contractually obliged to make an appropriate effort, but frequently has interests that are in opposition to this: the principal wishes to see the highest possible effort level for his money, and the agent has incentives to obtain this money with minimal effort. The approaches that economic contract theory has prepared for this occasion do not lead to an efficient solution, but only to the best possible answer to information asymmetry (the so-called second-best solution).

At this point, I must make do with these outlines. In order to conduct a serious analysis, the individual factors that are relevant for our context would have to be sought out (possibly empirically) and then formalized so that we could introduce them into the theoretical world of the model. Only a precise formalization allows one to draw clear theoretical conclusions, which in turn would require empirical examination. Applying the theoretical approaches we have dealt with to the question of representation, however, seems a promising approach. On the one hand, such an application shows that politicians may have substantial incentives, independently of parties, to pursue other interests than those of common welfare; on the other hand, it also shows how one can try to gear the interests of the representatives towards the interests of the represented. We can also expect to see proof that a number of mechanisms that can be deduced from contract theory, for instance, are already firmly established in constitutional theory; they would thus gain a further theoretical justification.

\section{The existence of a popular will that can be traced back to individual preferences}

Finally, New Political Economy shall help us here to show why the reference point of the idea of representation - a form of popular will that can be traced back to individual preferences - seems questionable. This has to do with a fundamental, principal problem of aggregating individual preference orders to a social welfare function, as shown by the Nobel Prize winner Kenneth Arrow in his dissertation Social Choice and Individual Values in 1951. He asked whether it is possible systematically to find a voting or election process that can be universally applied, fulfilling all criteria he deemed necessary for an election - and he proved mathematically, by means of his so-called impossibility theorem, that there cannot be such a procedure. 
Arrow postulates four requirements for a voting or election system:

- First, the result of an election procedure, i.e., the collective preference order, must be transitive. In other words, preferences must be arranged such that for three options, $a, b$ and $c$, the following is valid: if $\mathrm{a}>\mathrm{b}$ and $\mathrm{b}>\mathrm{c}$, then it must follow that $\mathrm{a}>\mathrm{c}$.

- Second, the collective ranking of two options must be independent of irrelevant alternatives.

- Third, the collective decision must be based upon the preferences of the group members, i.e., if all voters prefer one option to another, this should reflect in the collective decision (Pareto criterion).

- Fourth, there must be no dictator, i.e., no individual whose preferences automatically determine the collective decision.

On the basis of these four assumptions, Arrow has shown that it is always possible, with three or more options at the disposal of two or more voters, to detect or shape a preference order that makes it impossible to find a consistent collective decision. Every possibly election procedure either breaches one of the four criteria or is not universally applicable. ${ }^{57}$

Arrow's proof ultimately means that, for reasons of principle, there can be no popular will that can rationally be attributed to an aggregation of individual preferences. A pragmatic objection, namely that we rarely vote on more than three options and that the impossibility theorem hence takes effect only in exceptional cases, ${ }^{58}$ is futile because it disregards the complexity of political decisions and their contextuality. For popular will, which the traditional representation principle takes as a frame of reference, is not the will that is formed in a single election - say, between two options available for a healthcare reform. Such elections, intended to be plebiscitary, do not exist in practice. Further, even the linking of such elections

57 Scores of mathematicians and economists attempt to sidestep this implacable insight by developing models that try to soften individual criteria - so far, without much success. For the dictator and the Pareto criterion, a modification is not up for discussion. With transitivity, compromises might indeed be reached - perhaps it suffices merely to determine the winner of an election - , but further developments of Arrow's theorem have shown that there are significant difficulties even then. Whether the criterion of independence of irrelevant alternatives should be softened or given up altogether is indeed being discussed; however, what are still lacking are good reasons that may rationalize an election procedure that contravenes this criterion. With regard to the criterion of universality, there is hope: much research is being conducted to develop models offering - for certain situations - procedures that could avoid our problems. For the political theory discourse, a set of alternative models seems interesting that does not presuppose completely arbitrary preference orders of voters but well-ordered political conflicts. — On this, see also the synopsis in A. Sen, The Possibility of Social Choice, Nobel Lecture, American Economic Review 89 (1999), pp. $349 \mathrm{ff}$.

Moreover, for the sake of completeness, it shall be noted that the Downsian median voter theorem described above may be considered one solution to the Arrow theorem: If an aggregation of preferences at the median is successful, this preference order meets all criteria postulated by Arrow. However, the Downsian model assumptions (cf. fn. 43), especially the one-dimensional policy space and the singlepeaked preferences of voters, may hardly be met in reality.

Hartmann, Eigeninteresse (fn. 41), p. 22. 
would lead to the problems described by Arrow. But even a single voting decision, for instance Bundestag elections, can mean that the voter decides on a string of political choices, using his first vote and his second vote (Erst- und Zweitstimme). The problem becomes particularly salient when we look at popular will in the context of the Federal budget: how should tax revenues be used, and how should expenditures on social, educational or military issues be prioritized and weighted? A popular will that can in some way be rationally traced back to citizens' preferences cannot be formed. And if it cannot be formed, popular will cannot be represented. Interestingly, this is not only the case of popular will, but for any form of collective will, so it is just valid for "party will" and for the representation of the "party people" in the democratically constituted organs of the party. This means we can no longer even claim that a party represents a particular section of the people.

Representation can then no longer be understood as mirroring the people, but only in the sense of delegation - parliamentarians do not make decisions according to the will of the people, but instead of the people.

\section{Consequences}

What consequences can we draw from our reflections on the representation principle in light of New Political Economy? On the whole, there is a discrepancy between normative standards and the political reality, which only fosters doubts about the implementation of the normative conception of the Grundgesetz. First of all, it has become evident that the idea of representation cannot refer to the people's will; if we wish to stick to it, we would need to specify what it refers to and how it ought to be designed. Secondly, it has become clear that parliamentarians have significant incentives, even without parties, to pursue particular interests, and that these incentives become even more prominent in the party state. The fact that parliamentarians and parties - in addition to parliamentarians in their allegiance to their parties - follow these incentives seems plausible and is widely acknowledged; just how large these effects are in the political reality would have to be empirically examined. At any rate, a representative concept of democracy cannot realistically refer to the representation of the entire people. Nor can an individual parliamentarian, a party or the entire parliamentary system be understood as representing the entire people.

The three scholars of constitutional theory, whom I have discussed here 'representatively' (?), and perhaps somewhat pointedly made the archetypal protagonists in the dispute on representation - Leibholz, Hesse and Stolleis - followed the three paths that seem to me to be possible solutions to the problem of representation. For Hesse, the concept of representation plays no major role, and one might even say, albeit exaggerating slightly, that he gave up on it. If there is no convincing concept of representation to be found, this will have to be the consequence. For Leibholz and Stolleis, the concept of representation plays an important part, namely one that legitimizes the democratic state. The idea of a voluntative linking of the state 
to the people it is destined to serve is highly captivating. These two scholars hence follow a different path. Leibholz gives up the idea of representation, only to replace it with a new legitimation idea - identity - that makes the will of the people pivotal to democratic power. Finally, for lack of a sustainable alternative concept, Stolleis maintains the idea of representation, albeit as a fiction, but he wishes to modify the way in which representation is understood, on the one hand, and, on the other, he wishes to ensure by means of institutions that the concept of representation can come into effect, i.e., primarily avert disruptions.

These three possibilities are open to us even today. Leibholz followed one of these paths until the end, with a concrete alternative; he was unable to find a sustainable solution. Modern constitutional theory must continue to search for it. 